University of Nebraska - Lincoln

DigitalCommons@University of Nebraska - Lincoln

Publications from USDA-ARS / UNL Faculty

U.S. Department of Agriculture: Agricultural

Research Service, Lincoln, Nebraska

2012

\title{
Links among Nitrification, Nitrifier Communities, and Edaphic Properties in Contrasting Soils Receiving Dairy Slurry
}

\author{
Ann-Marie Fortuna \\ Washington State University, afortuna@wsu.edu \\ C. Wayne Honeycutt \\ USDA-ARS \\ George Vandemark \\ USDA-ARS, george.vandemark@ars.usda.gov \\ Timothy S. Griffin \\ Tufts University, timothy.griffin@tufts.edu \\ Robert P. Larkin \\ USDA-ARS, bob.larkin@ars.usda.gov \\ See next page for additional authors
}

Follow this and additional works at: https://digitalcommons.unl.edu/usdaarsfacpub

Fortuna, Ann-Marie; Honeycutt, C. Wayne; Vandemark, George; Griffin, Timothy S.; Larkin, Robert P.; He, Zhongqi; Wienhold, Brian J.; Sistani, Karamat R.; Albrecht, Stephan L.; Woodbury, Bryan L.; Torbert, Henry A.; Powell, J. Mark; Hubbard, Robert K.; Eigenberg, Roger A.; Wright, Robert J.; Alldredge, J. Richard; and Harsh, James B., "Links among Nitrification, Nitrifier Communities, and Edaphic Properties in Contrasting Soils Receiving Dairy Slurry" (2012). Publications from USDA-ARS / UNL Faculty. 1202.

https://digitalcommons.unl.edu/usdaarsfacpub/1202

This Article is brought to you for free and open access by the U.S. Department of Agriculture: Agricultural Research Service, Lincoln, Nebraska at DigitalCommons@University of Nebraska - Lincoln. It has been accepted for inclusion in Publications from USDA-ARS / UNL Faculty by an authorized administrator of DigitalCommons@University of Nebraska - Lincoln. 


\section{Authors}

Ann-Marie Fortuna, C. Wayne Honeycutt, George Vandemark, Timothy S. Griffin, Robert P. Larkin, Zhongqi He, Brian J. Wienhold, Karamat R. Sistani, Stephan L. Albrecht, Bryan L. Woodbury, Henry A. Torbert, J.

Mark Powell, Robert K. Hubbard, Roger A. Eigenberg, Robert J. Wright, J. Richard Alldredge, and James B. Harsh 


\title{
Links among Nitrification, Nitrifier Communities, and Edaphic Properties in Contrasting Soils Receiving Dairy Slurry
}

\author{
Ann-Marie Fortuna, ${ }^{*}$ C. Wayne Honeycutt, George Vandemark, Timothy S. Griffin, Robert P. Larkin, Zhongqi He, \\ Brian J. Wienhold, Karamat R. Sistani, Stephan L. Albrecht, Bryan L. Woodbury, Henry A. Torbert, J. Mark Powell, \\ Robert K. Hubbard, Roger A. Eigenberg, Robert J. Wright, J. Richard Alldredge, and James B. Harsh
}

Soil biotic and abiotic factors strongly influence nitrogen $(\mathrm{N})$ availability and increases in nitrification rates associated with the application of manure. In this study, we examine the effects of edaphic properties and a dairy (Bos taurus) slurry amendment on $\mathrm{N}$ availability, nitrification rates and nitrifier communities. Soils of variable texture and clay mineralogy were collected from six USDA-ARS research sites and incubated for $28 \mathrm{~d}$ with and without dairy slurry applied at a rate of $-300 \mathrm{~kg} \mathrm{~N} \mathrm{ha}^{-1}$. Periodically, subsamples were removed for analyses of $2 \mathrm{M} \mathrm{KCl}$ extractable $\mathrm{N}$ and nitrification potential, as well as gene copy numbers of ammonia-oxidizing bacteria (AOB) and archaea (AOA). Spearman coefficients for nitrification potentials and AOB copy number were positively correlated with total soil C, total soil $\mathrm{N}$, cation exchange capacity, and clay mineralogy in treatments with and without slurry application. Our data show that the quantity and type of clay minerals present in a soil affect nitrifier populations, nitrification rates, and the release of inorganic N. Nitrogen mineralization, nitrification potentials, and edaphic properties were positively correlated with AOB gene copy numbers. On average, AOA gene copy numbers were an order of magnitude lower than those of $\mathrm{AOB}$ across the six soils and did not increase with slurry application. Our research suggests that the two nitrifier communities overlap but have different optimum environmental conditions for growth and activity that are partly determined by the interaction of manure-derived ammonium with soil properties.
Copyright $\odot 2012$ by the American Society of Agronomy, Crop Science Society of America, and Soil Science Society of America. All rights reserved. No part of this periodical may be reproduced or transmitted in any form or by any means, electronic or mechanical, including photocopying, recording, or any information storage and retrieval system, without permission in writing from the publisher.

J. Environ. Qual. 41:262-272 (2012)

doi:10.2134/jeq2011.0202

Posted online 16 Nov. 2011.

Received 7 June 2011.

${ }^{*}$ Corresponding author (afortuna@wsu.edu).

(c) ASA, CSSA, SSSA

5585 Guilford Rd., Madison, WI 53711 USA
B EST MANAGEMENT PRACTICES for application of manure should take into account the linkages among $\mathrm{N}$ cycling, edaphic factors, and microbial communities that affect the fate of plant available $\mathrm{N}$ from organic fractions. Manure $\mathrm{N}$ excreted from animal production systems in the United States exceeds 28 million metric tons annually, representing a valuable source of nutrients (USDA-ERS, 2001). Less than $40 \%$ of manure $\mathrm{N}$ is recycled to cropland, while 11 million metric tons of $\mathrm{N}$ fertilizer is purchased annually (USDA-NASS, 2004). Therefore, accurate predictive measures of manure $\mathrm{N}$ transformations could potentially reduce input costs and excess nutrient loading to the environment.

High clay content can increase the amount of total soil $\mathrm{N}$ by physically protecting soil organic matter (SOM) (Bosatta and Agren, 1998). Greater concentrations of SOM have been shown to support larger populations of microorganisms that foster increased potential for mineralization and possibly nitrification (Accoe et al., 2004). Gross $\mathrm{N}$ mineralization rates have been correlated with total soil N (TSN) content (Accoe et al., 2004). Soils containing vermiculitic and smectitic clays can fix a portion of ammonium applied in fertilizers and manures due to the presence of expanding interlayers in these clays (Bajwa, 1982; Meunier and Velde, 2004). Kaolinite does not allow for fixation of $\mathrm{NH}_{4}^{+}$because the tetrahedral and octahedral sheets do not allow for expansion. Chloritic clays do not fix $\mathrm{NH}_{4}^{+}$ due to the presence of a hydroxide sheet in their interlayers.

A.-M. Fortuna and J.B. Harsh, Dep. of Crop \& Soil Sci., Washington State Univ., Pullman, WA 99164-6420; C.W. Honeycutt, USDA-ARS, Orono, ME; G. Vandemark, USDA-ARS, Pullman, WA; T.S. Griffin, Tufts Univ., Boston, MA; R.P. Larkin and Z. He, USDA-ARS, New England Plant, Soil and Water Lab., Orono, ME; B.J. Wienhold, USDA-ARS, Lincoln, NE; K.R. Sistani, USDA-ARS, Bowling Green, KY; S.L. Albrecht, USDA-ARS, Pendleton, OR; B.L. Woodbury and R.A. Eigenberg, USDA-ARS, Clay Center, NE; H.A. Torbert, USDAARS, Auburn, AL; J.M. Powell, USDA-ARS, Madison, Wl; R.K. Hubbard, USDA-ARS, Tifton, GA; R.J. Wright, USDA-ARS, Beltsville, MD; J.R. Alldredge, Dep. of Statistics, Washington State Univ., Pullman, WA; C.W. Honeycutt, current address: USDA-NRCS, Washington, DC. Assigned to Associate Editor Søren O. Petersen.

\footnotetext{
Abbreviations: $A O A$, ammonia-oxidizing archaea; $A O B$, ammonia-oxidizing bacteria; $B D$, bulk density; $C E C$, cation exchange capacity; $L \_N E$, loam, Newport soil; PCR, polymerase chain reaction; PVC, polyvinyl chloride; PVP, polyvinylpolypyrrolidone; qPCR, quantitative polymerase chain reaction; S_VA, sand, Valentine soil series; SIC_CA, silty clay loam, Catlin soil series; SIC_SH, silty clay, Sharpsburg soil series; SICL_BR, silty clay loam, Brooksville; SIL_CA, loam, Caribou soil series; SIL_LO, silt loam, Loyal soil series; SIL_RO, silt loam, Roshalt soil series; SL_ $A D$, sandy loam, Adkins soil series; SOC, total soil organic carbon; SOM, soil organic matter; TSN, total soil nitrogen; VR, vermiculite; WFPS, water-filled pore space.
} 
Therefore, research that emphasizes clay mineralogy, as well as textural class, is needed to improve estimates of the wide range of plant-available $\mathrm{N}$ and nitrification rates that occur when a particular manure is applied to soils of differing mineralogy.

Nitrification potential is the maximum capacity of nitrifying bacteria and archaea to transform $\mathrm{NH}_{4}-\mathrm{N}$ to $\mathrm{NO}_{3}-\mathrm{N}$ via a two-step process in which ammonium is oxidized and converted to nitrite and nitrite is converted to nitrate. Oxidation of ammonium to nitrite is the rate-limiting step and is catalyzed by the ammonia monooxygenase enzyme (amoA). Until recently, ammonia-oxidizing bacteria (AOB) were thought to be the sole group of organisms in marine and soil systems capable of converting ammonia to nitrite chemolithoautotrophically. Probes designed to isolate the gene encoding a subunit of the enzyme ammonia monooxygenase $(a m o A)$ revealed the presence of amoA in Archaea (Leininger et al., 2006; Wuchter et al., 2006). The use of quantitative polymerase chain reaction (qPCR) further revealed that archaea containing the amo $A$ gene inhabit a range of environments that include marine and fresh water, terrestrial soil systems, and wastewater treatment facilities (Leininger et al., 2006; You et al., 2009).

Edaphic properties, land-use management, and ecosystem characteristics select for different ratios of $\mathrm{AOB}$ to ammonia-oxidizing archaea (AOA) and influence the size of each nitrifier community that can be supported, leading to potential variations in nitrification rates (Lehtovirta et al., 2009; Nicol et al., 2004; Taylor et al., 2010; Webster et al., 2005). Ammonia-oxidizing bacteria can proliferate in environments at higher $\mathrm{NH}_{4}^{+}$concentrations and typically respond to ammonia additions. Although archaea containing the amo $\mathrm{A}$ gene have been isolated from wastewater treatment facilities (You et al., 2009), most archaea containing the amo $A$ gene have been isolated from oligotrophic environments (MartensHabbena et al., 2009).

Nitrifying AOA are often found in higher numbers relative to $A O B$ in grassland systems that are often $\mathrm{N}$ limited, resulting in decreased nitrification rates. Grasslands can select for higher AOA numbers and have been shown to support higher AOA activity relative to agronomic managements that are dominated by AOB activity (Taylor et al., 2010). The presence and activity of AOA in six managed grasslands did not vary with ammonia additions, whereas $\mathrm{AOB}$ copy numbers and activity increased with additions (Di et al., 2009). Nitrifying archaea are present in high numbers in agronomic systems receiving higher $\mathrm{N}$ inputs than natural systems. However, AOA growth in agricultural soils has been shown to remain constant after addition of ammonia (Di et al., 2010; Jia and Conrad, 2009). Previous studies showed that application of pig manure, inorganic fertilizer, or sheep urine to soils stimulated AOB growth but had little effect on AOA growth (Nicol et al., 2004; Schauss et al., 2009).

Few if any studies have been conducted to address the role of $\mathrm{AOA}$ relative to $\mathrm{AOB}$ in the nitrification process across a range of soils of varying edaphic properties in agronomic systems. This research examines changes in nitrification rates and $\mathrm{AOA}, \mathrm{AOB}$ gene copy numbers per gram of soil resulting from manure application to nine soils of differing clay mineralogy, total soil organic C (SOC), TSN, and fertility under controlled conditions. Adding manure to previously unamended soils with no $\mathrm{N}$ input for several years allowed for the comparison of soil properties by eliminating the effects of recent management. Microbial community shifts were expected to be more dramatic after manure additions to soils with limited nitrogen. The inclusion of a range of soils from several regions in the United States enabled us to assess which chemical, physical, and biological characteristics of a given soil had the strongest influence on nitrifiers, nitrification, and $\mathrm{N}$ cycling. We correlated measurements of nitrification potentials with $\mathrm{AOA}, \mathrm{AOB}$ copy numbers, and soil properties after application of manure $\mathrm{N}$ to evaluate the subsequent effects of this $\mathrm{N}$ source on the nitrification processes. An additional objective was to evaluate whether potential niches of $\mathrm{AOA}$ and $\mathrm{AOB}$ communities are consistent across a range of manure-amended soils.

\section{Materials and Methods Study Sites}

Field samples were collected from USDA-ARS research centers across a range of soil series with differing clay mineralogy in the United States (Tables 1 and 2). Soil abbreviations

Table 1. Soil series and selected management information for soils used in this study.

\begin{tabular}{|c|c|c|c|c|c|}
\hline State & $\begin{array}{l}\text { Soil series } \\
\text { abbreviation }\end{array}$ & Soil series description & Vegetation & Previous cropping history & Tillage \\
\hline \multirow[t]{2}{*}{ Maine } & Caribou SIL_CA & fine-loamy, mixed, frigid Typic Haplorthod & weedy fallow & $7 \mathrm{yr}$ since last crop of potatoes & $\begin{array}{l}\text { discing, } \\
\text { mowed }\end{array}$ \\
\hline & Newport L_NE & $\begin{array}{l}\text { unnamed variant of a Bangor series; coarse } \\
\text { loamy, mixed frigid Typic Haplorthod }\end{array}$ & annual sod & none & none \\
\hline \multirow[t]{2}{*}{ Nebraska } & Sharpsburg SIC_SH & fine, montmorillonitic, mesic, Typic Argiudoll & wheat stubble & soybean & no tillage \\
\hline & Valentine S_VA & mixed, mesic, Typic Ustipsamment & $\begin{array}{l}\text { native short } \\
\text { grass prairie }\end{array}$ & grazed & none \\
\hline Oregon & Adkins SL_AD & $\begin{array}{l}\text { coarse-loamy, mixed, mesic, Xerollic } \\
\text { Camborthid }\end{array}$ & sagebrush & none & none \\
\hline \multirow[t]{2}{*}{ Wisconsin } & Loyal SIL_LO & $\begin{array}{l}\text { fine-loamy, mixed, superactive frigid } \\
\text { Oxyaquic Glossudalfs }\end{array}$ & corn & Corn & chisel \\
\hline & Roshalt SIL_RO & $\begin{array}{l}\text { coarse-loamy, mixed, superactive, frigid } \\
\text { Haplic Glossudalf }\end{array}$ & corn & soybean/corn & chisel \\
\hline Mississippi & Brooksville SICL_BR & fine, smectitic, thermic Aquic Hapludert & $\begin{array}{l}\text { grass border } \\
\text { of field }\end{array}$ & not cropped for at least $5 \mathrm{yr}$ & none \\
\hline Illinois & Catlin SIC_CA & $\begin{array}{l}\text { fine-silty, mixed, superactive mesic } \\
\text { Oxyaquic Arguidoll }\end{array}$ & $\begin{array}{l}\text { grass border } \\
\text { of field }\end{array}$ & not cropped for at least $5 \mathrm{yr}$ & none \\
\hline
\end{tabular}


were derived from the Soil Survey textural class abbreviations and the first two letters of the soil series: SICL_BR—silty clay loam, Brooksville; SIC_CA—silty clay loam, Catlin soil series; SIC_SH—silty clay, Sharpsburg soil series; L_NE—loam, Newport soil; S_VA—sand, Valentine soil series; SIL_CAloam, Caribou soil series; SIL_LO_silt loam, Loyal soil series; SIL_RO—silt loam, Roshalt soil series; SL_AD—sandy loam, Adkins soil series (Table 1). The soil series designation is used to distinguish soils of the same textural class from one another. Soil samples were collected between 29 Apr. and 8 Aug. 2005. All soil samples were taken in areas that had received no $\mathrm{N}$ inputs for $5 \mathrm{yr}$ and no manure for $10 \mathrm{yr}$. Three sites were located on grasslands. The Valentine series was sampled from a native short grass prairie, Adkins was sampled from sagebrush, and Newport was in annual sod. The remaining sites were previously cropped or on the border of a field (Table 1).

\section{Sample Collection}

Soils at each location were randomly sampled by collecting 12 cores within a $2-\mathrm{m}^{2}$ area to $15-\mathrm{cm}$ depth using polyvinyl chloride (PVC) inserts of $689-\mathrm{cm}^{3}$ volume and a sliding drop hammer. The inserts prevented soil compaction and allowed us to measure soil bulk density. Each PVC insert containing field moist soil was capped at both ends, placed in a cooler, and shipped to the New England Plant, Soil and Water Laboratory in Orono, ME. The Catlin soil samples from Illinois were collected to an approximate $15-\mathrm{cm}$ depth using a shovel, and field moist soil were transported at ambient temperature for $1 \mathrm{wk}$.

Each of the 12 field moist soil cores from a given soil series was pooled, sieved through a $2-\mathrm{mm}$ sieve, and weighed. Three replicate $10-\mathrm{g}$ subsamples were collected from each sieved core for determination of gravimetric water content. Bulk density (BD) was calculated for each core (Blake and Hartge, 1986). Bulk soil was stored at $4^{\circ} \mathrm{C}$ in the laboratory before the start of the experiment. Disturbance resulting from sampling often causes a 2-wk initial flush of mineralization that may interfere with estimates of potentially mineralizable N (Stanford and Smith, 1972; Curtin and Campbell, 2008). Because of the differences in the size of the potential flush among soil series, soils were preincubated. All soils, except for the Catlin, were preincubated at $25^{\circ} \mathrm{C}$ for $2 \mathrm{wk}$. The week the Catlin soil was in transport was considered week 1 of a 2 -wk preincubation.

\section{Soil Properties}

Soil samples were analyzed for SOC and TSN. A set of soil samples was prepared for dry combustion by pulverization in a Wig-L-Bug amalgamator/mixer (Cresent, Elgin, IL). Total soil organic $\mathrm{C}$ and TSN were measured via dry combustion on a LECO CN-2000 (Leco Corporation, St. Joseph, MI). The $\mathrm{pH}$ of soils was measured via the method of McLean (1982). Cation exchange capacity $\left(\mathrm{CEC}, \mathrm{cmol}_{\mathrm{c}} \mathrm{kg}^{-1}\right)$ was estimated as the $\Sigma(\mathrm{Ca}+\mathrm{Mg}+\mathrm{K}+\mathrm{Na}$ ) (Ross, 1995). Exchangeable acidity was negligible.

\section{Mineralogy}

Mineralogical data from the clay fraction $(<2 \mu \mathrm{m}$ diameter $)$ was processed at the USDA-NRCS National Soil Survey Center Soil Survey Laboratory. The clay fraction was separated from other dispersed soil separates via centrifugation (Moore and Reynolds, 1997). Chlorite, goethite, illite, kaolinite, quartz, smectite, and vermiculite were determined by standard X-ray diffraction techniques (Whittig and Allardice, 1986). Continuous, locked coupled scans were obtained at 0.0545-s time steps at $0.02^{\circ} 2$-theta and a slit of $1.000^{\circ} 2$-theta. A quartz standard was used to measure peak height drift and periodically corrected with time-step adjustments. In addition, a soil standard was included in each set of scans as a check for constant behavior of clay mineral patterns. Counts per second values were used in the statistical analysis. Each mineral was also assigned to one of five semiquantitative classes used for soil survey classification based on peak height above background (counts s${ }^{-1}$ ). Classes include 5 (very large, $>1800$ counts s$^{-1}$ ), 4 (large, 1120-1800 counts $\mathrm{s}^{-1}$ ), 3 (medium, 360-1120 counts s $\mathrm{s}^{-1}$ ), 2 (small, 110-360 counts $\mathrm{s}^{-1}$ ), and 1 (very small, $<110$ counts s$^{-1}$ ) (Burt, 2004). We divided the illite class by the sum of all mineral classes for a given soil to approximate the potential for illite to adsorb $\mathrm{NH}_{4}$ at selective sites ("fixed" $\mathrm{NH}_{4}$ ). The quantity of selective sites was estimated as $3 \%$ of the

Table 2. Biotic, abiotic and chemical properties of soils used to assess nitrification, cumulative inorganic $\mathbf{N}$ and ammonia oxidizer (AOB) gene copy number $\mathrm{g}^{-1}$ soil in soils with and without dairy slurry applications.

\begin{tabular}{|c|c|c|c|c|c|c|c|c|c|c|}
\hline $\begin{array}{c}\text { Sample } \\
\text { code }\end{array}$ & Texture & Mineralogy†‡ & Sand & Silt & Clay & soc§ & TSN§ & $\begin{array}{c}\mathrm{pH} \\
0.01 \mathrm{M} \mathrm{CaCl}_{2} \\
\end{array}$ & BD§ & CEC§ \\
\hline & & & \multicolumn{3}{|c|}{$-\mathrm{g} \mathrm{kg}^{-1}-$} & \multicolumn{3}{|c|}{$-\mathrm{g} \mathrm{kg}^{-1}$ soil - } & $\mathrm{g} \mathrm{cm}^{-3}$ & $\mathrm{cmol}_{\mathrm{c}} \mathrm{kg}^{-1}$ \\
\hline SIL_CA & silt loam & KK 2 IL 2 S 2 & 370 & 510 & 120 & 20 & 1.7 & 5.2 & 1.2 & 6.62 \\
\hline L_NE & loam & KK 2 IL 3 S 3 & 430 & 430 & 140 & 25 & 2.0 & 5.2 & 1.2 & 4.75 \\
\hline SIC_SH & silty clay & KK 2 IL 2 VR 2 & 30 & 570 & 400 & 19 & 1.7 & 5.4 & 1.3 & 21.9 \\
\hline S_VA & sand & KK 2 IL 2 S 2 & 930 & 40 & 30 & 5.0 & 0.5 & 5.4 & 1.4 & 3.47 \\
\hline SL_AD & sandy loam & KK 1 IL 2 S 2 & 730 & 210 & 60 & 5.8 & 0.6 & 6.4 & 1.5 & 10.1 \\
\hline SIL_LO & silt loam & KK 2 IL 1 VR 2 & 120 & 720 & 160 & 23 & 2.1 & 6.2 & 1.4 & 13.5 \\
\hline SIL_RO & silt loam & KK 3 IL 1 VR 2 & 300 & 600 & 100 & 13 & 1.2 & 4.5 & 1.5 & 4.62 \\
\hline SICL_BR & silty clay loam & KK 4 S 3 & 100 & 580 & 320 & 23 & 2.1 & 6.2 & 1.3 & 31.0 \\
\hline SIC_CA & silty clay & KK 2 S 3 IL 2 VR 1 & 190 & 410 & 400 & 35 & 2.5 & 7.0 & 1.3 & 25.4 \\
\hline
\end{tabular}

† Mineral interpretation: KK, kaolinite; IL, illite; S, smectite; VR, vermiculite.

Mineralogical data provided by the USDA-NRCS National Soil Survey Center Soil Survey Laboratory.

\# Relative peak size: 5 , very large; 4 , large; 3 , medium; 2 , small; 1, very small. Measured via X-ray diffraction.

§ SOC, soil organic carbon sample depth 0-15 cm 2005; TSN, total soil nitrogen sample depth $0-15 \mathrm{~cm} \mathrm{2005;} \mathrm{BD,} \mathrm{soil} \mathrm{bulk} \mathrm{density} \mathrm{and} \mathrm{BD} \mathrm{of} \mathrm{soil} \mathrm{in} \mathrm{incu-}$ bation vessels; $\mathrm{CEC}$, cation exchange capacity, $\Sigma(\mathrm{Ca}+\mathrm{Mg}+\mathrm{K}+\mathrm{Na})$ from the Mehlich III extract-exchangable acidity and Na were negligible. 
average CEC of illite $30 \mathrm{cmol}_{\mathrm{c}} \mathrm{kg}^{-1}-0.9 \mathrm{cmol}_{\mathrm{c}} \mathrm{kg}^{-1}$ (Meunier and Velde, 2004).

\section{Soil Incubations and Nitrogen Analyses}

A portion of the soil collected from each soil series was used in a 28-d laboratory incubation. Each soil series contained five time points (Day 0, 7, 14, 21, and 28), four replicates, and two treatments, soil amended with dairy slurry and an unamended control soil. The $\mathrm{pH}$ of the dairy slurry was measured by the method of Wolf (2003). A pH electrode was immersed into a mixture of $40 \mathrm{~mL}$ of deionized $\mathrm{H}_{2} \mathrm{O}$ and $20 \mathrm{~mL}$ of dairy slurry. The $\mathrm{pH}$ of the slurry was 7.2 . Field-moist soil, equal to $50 \mathrm{~g}$ of dry soil, was weighed into $120-\mathrm{mL}$ specimen vials (53 mm diam., $60 \mathrm{~mm}$ height). The soil height in the specimen vials was approximately $35 \mathrm{~mm}$. Soils were packed to the equivalent $\mathrm{BD}$ of each soil series at the time of field sampling. Two grams of dairy slurry were applied directly to the surface of soils receiving the slurry. The slurry moved into the soil from the surface within a few minutes and migrated approximately $15 \mathrm{~mm}$, after which the top 1 to $2 \mathrm{~cm}$ of soil were turned over and the $\mathrm{BD}$ restored. This operation simulated incorporation of the dairy slurry and minimized ammonia volatilization. Incubations were conducted at $25^{\circ} \mathrm{C}$ and $60 \%$ of water-filled pore space (WFPS); following initial manure additions, distilled $\mathrm{H}_{2} \mathrm{O}$ was added to bring soil in incubation vials up to $60 \%$ of WFPS. Once a week, soil samples were aired and weighed and water added to maintain WFPS at $60 \%$. Specimen vials were then rearranged in the incubator to account for potential variability within the incubator. Eight specimen vials, four replicates of each treatment, were removed per soil series at each sampling. Subsamples $(20 \mathrm{~g})$ were taken from each specimen vial for inorganic $\mathrm{N}$ analysis $\left(\mathrm{NH}_{4}, \mathrm{NO}_{2}\right.$, and $\left.\mathrm{NO}_{3}\right)-\mathrm{N}$, nitrification potential, and qPCR measurements, respectively. Each subsample was taken as a wedge from the center of the specimen vial to the edge of the vessel and included soil from 0 to $35 \mathrm{~mm}$.

Inorganic $\mathrm{N},\left(\mathrm{NH}_{4}, \mathrm{NO}_{2}\right.$, and $\left.\mathrm{NO}_{3}\right)-\mathrm{N}$, was extracted with $100 \mathrm{~mL}$ of $2 \mathrm{M} \mathrm{KCl}$. Aliquots were run on an automated, continuous flow OI Analytical ALPKEM Flow Solution IV Auto-Analyzer (OI Analytical, College Station, TX) to determine ammonium $\mathrm{N}$ using the salicylate-nitroprusside method (Mulvaney, 1996) and the cadmium reduction method for combined nitrate N plus nitrite-N (Gavlak et al., 1994). Nitrite- and nitrate-N were not determined separately because nitrite concentrations are considered negligible $(<0.5 \%$ of $\mathrm{NO}_{3}+\mathrm{NO}_{2}$ ) under conditions comparable to our experiment (Smith et al., 1997).

The potential rate of nitrification was determined using 15 -g subsamples of soil via the shaken slurry method (Hart et al., 1994) for all soils except the Valentine sand. The coarse sand fraction of this soil settled too quickly to obtain a consistent soil-to-media ratio. Nitrate from the centrifuged supernatant was measured via an automated OI Analytical ALPKEM Flow Solution IV Auto-Analyzer as previously described.

\section{Ammonia Volatilization}

The dairy slurry contained inorganic $\mathrm{N}$ in the form of $\mathrm{NH}_{4}^{+}$ that could be lost as $\mathrm{NH}_{3}$. Therefore, a separate incubation experiment was conducted to measure the amount of ammo- nia volatilized from each soil series. Twenty-four grams of dairy slurry $\left(-300 \mathrm{~kg} \mathrm{~N} \mathrm{ha}^{-1}\right)$ were added to $200 \mathrm{~g}$ of soil maintained at $60 \%$ of WFPS and $25^{\circ} \mathrm{C}$ for $7 \mathrm{~d}$ with three replications. Ammonia was captured on acid traps consisting of filter paper treated with oxalic acid ( $3 \mathrm{~g}$ oxalic acid $\mathrm{L}^{-1}$ acetone) suspended in each incubation vessel following the procedure of Russell et al. (2004). Upon removal of traps, $\mathrm{NH}_{4}^{+}$was extracted with $100 \mathrm{~mL}$ of $2 \mathrm{M} \mathrm{KCl}$ and run on an automated OI Analytical ALPKEM Flow Solution IV Auto-Analyzer as previously described. Internal controls consisted of varying concentrations of ammonium persulfate, $\left(\mathrm{NH}_{4}\right)_{2} \mathrm{~S}_{2} \mathrm{O}_{8}$, dissolved in cold filtered $\mathrm{H}_{2} \mathrm{O}$. Magnesium oxide $(\mathrm{MgO})$ was used as an alkali to drive off ammonium as ammonia gas $\left(\mathrm{NH}_{3}\right)$.

\section{Quantification of Ammonia-0xidizing Archaea and Ammonia-0xidizing Bacteria by qPCR}

We selected soil series with contrasting soil properties and nitrogen parameters (SIC_CA, SIL_CA, SIC_SH, SL_AD, SIL_RO, and SIL_LO) for molecular analyses. The Valentine soil (S_VA) was not included because it was too coarse a sand to be analyzed via nitrification potential (see "Materials and Methods," Soil Incubations and Nitrogen Analyses), preventing correlations of nitrification rates with $\mathrm{AOA}, \mathrm{AOB}$ copy numbers. The Newport soil (L_NE) and Brooksville soils (SICL_BR) contained soil components that inhibited qPCR analysis. These samples were treated with a polyvinylpolypyrrolidone (PVP) P6755 (Sigma-Aldrich) suspension, in sterile water, $10 \% \mathrm{w} / \mathrm{v}$. Quantitative polymerase chain reaction reactions amplified successfully after the additional clean-up step with PVP. But copy numbers of $\mathrm{AOB}$ and $\mathrm{AOA}$ were lower than typically reported in the literature. The additional PVP step may have removed a portion of the $\mathrm{AOA}, \mathrm{AOB}$ genomic DNA, and inhibition of polymerase chain reaction (PCR) reactions did not appear to be completely eliminated. Therefore, due to inhibition and the difference in treatment of genomic DNA from L_NE and SICL_BR, these samples were not included in the data analysis. The AOB copy numbers were higher than AOA copy numbers in both soils.

Genomic DNA was extracted with a MoBio Power Soil DNA Isolation Kit (MO BIO Laboratories, Inc., Carlsbad, CA) from soil subsamples taken on Days 0 and 28 of the incubations from control and manure-amended soils. Genomic DNA was frozen at $-80^{\circ} \mathrm{C}$ for use in qPCR analyses.

Quantitative PCR assays were conducted to quantify betaproteobacterial $A O B$-specific $16 S$ rRNA gene sequences and the AOA-specific amo $A$ gene encoding for the ammonium monooxygenase enzyme. Primers specific for AOB were used to amplify a 116-bp DNA fragment in the $\mathrm{V} 2$ region of the $16 \mathrm{~S}$ ribosomal DNA: CTO 189fA/B GGAGRAAAGCAGGGGATCG, CTO 189fC GGAGGAAAGTAGGGGATCG, RT1r CGTCCTCTCAGACCARCTACTG, and the probe, TMP1 CAACTAGCTAATCAGRCATCRGCCGCTC (Hermansson and Lindgren, 2002) labeled at the $5^{\prime}$ terminus with fluorochromo 6-carboxyfluorescein (FAM) and a quencher dye tetra-methylcarboxyrhodamine (TAMRA) at the $3^{\prime}$ terminus. The primers and TaqMan probe were synthesized by Applied Biosystems, Inc. (Foster City, CA). Use of the CTO primers diagnostic for the $16 \mathrm{~S}$ rRNA gene containing a single region 
specific to ammonia oxidizers of the beta subdivision of Proteobacteria (Aakra et al., 2000) reducing the potential bias caused by the presence of variable copy numbers of the amo $A$ operon in the genomes of different AOB strains (Norton et al., 2002) reduced the bias caused when the multicopy amo $A$ gene is targeted instead (Aakra et al., 2000). Primers specific for archaeal amo $A$ were used to amplify a 635-bp DNA fragment: Arch-amoAF STAATGGTCTGGCTTAGACG and Arch-amoAR GCGGCCATCCATCTGTATGT (Taylor et al., 2010). The primers were synthesized by Applied Biosystems Inc. Each reaction contained a total volume of $25 \mu \mathrm{L}$ that included Universal PCR Master Mix (Applied Biosystems Inc.). The AOB qPCR reactions contained 7.5 pmol of each forward primer CTO 189fA/B and CTO189fC, $7.5 \mathrm{pmol}$ of the reverse primer RT1r, and 3 pmol of TaqMan probe TMP1. The AOA qPCR reactions contained 3.75 pmol of forward Arch-amoAF and reverse Arch-amoAR primer. Standard curves for $\mathrm{AOB}$ were generated using five different genomic DNA concentrations extracted from pure culture Nitrosomonas europaea ATCC 19718 ranging from 0.4 pg to 4 ng per qPCR reaction. Standard curves for AOA were generated using six different DNA concentrations of TOPO vector containing the Nitrosopumilus maritimus SCM1 strain genes amoBAC. DNA concentrations ranged from $4.4 \mathrm{fg}$ to $44 \mathrm{pg}$ per reaction. The TOPO vector containing Nitrosopumilus maritimus SCM1 strain amoBAC gene insert (EU239959) was kindly provided by Daniel Arp and David Myrold (Oregon State University, Corvallis, OR). The Arp laboratory received the original glycerol stocks containing the Nitrosopumilus maritimus TOPO vector (Invitrogen, Carlsbad, CA) from David Stahl, University of Washington, Seattle, WA. Genomic DNA template equivalent to $4 \mathrm{ng}(\mathrm{AOB})$ and $(\mathrm{AOA}) 0.4 \mathrm{ng}$ per reaction was used for each environmental sample. Reaction mixtures were amplified and measured in an ABI Prism 7500 (Applied Biosystems Inc.). Quantitative PCR reactions for AOB were performed using a default thermocycling profile that consisted of $2 \mathrm{~min}$ at $50^{\circ} \mathrm{C}, 10 \mathrm{~min}$ at $95^{\circ} \mathrm{C}$, followed by 40 cycles of $15 \mathrm{~s}$ at $95^{\circ} \mathrm{C}$ and $1 \mathrm{~min}$ at $60^{\circ} \mathrm{C}$; and for $\mathrm{AOA}, 10 \mathrm{~min}$ at $95^{\circ} \mathrm{C}$, followed by 40 cycles of $15 \mathrm{~s}$ at $95^{\circ} \mathrm{C}, 30 \mathrm{~s}$ at $55^{\circ} \mathrm{C}$, and $30 \mathrm{~s}$ at $72^{\circ} \mathrm{C}$ for AOA. The initial 2-min step at $50^{\circ} \mathrm{C}$ inactivates the AmpErase UNG contained in the master mix. AmpErase UNG is added to degrade PCR product contaminations that may be present when the PCR reactions are initially setup. The AmpErase UNG is activated at $50^{\circ} \mathrm{C}$, then inactived at the first cycle at $95^{\circ} \mathrm{C}$ before amplification of the amoA AOA gene.

Genomic DNA from environmental samples used in qPCR reactions was amplified and cloned to verify that the sequences obtained were $98 \%$ similar to AOA sequences. Polymerase chain reaction products were purified with a QIAquick PCR purification kit (Qiagen, Valencia, CA) and ligated into a pCR 2.1-TOPO cloning vector (Invitrogen, Carlsbad, CA) then heat-shocked into One Shot TOP10 chemically competent $E$. coli cells (Invitrogen). Resultant transformants were grown on LB amp 50 agar. Fifteen colonies were selected and grown in $5 \mathrm{~mL}$ of LB amp50. The 600-bp insert contained in the plasmids was isolated via digestion with EcoRI (Promega, Madison, WI). Sequencing reactions were set up using primers M13F: GTAAAACGACGGCCAG or M13R: CAGGAAACAGCTATGAC. Resultant sequences were run through a National Center for Biotechnology Information Blast search (www.ncbi.nlm.nih.gov/BLAST/) and aligned with a $98 \%$ max identity to "uncultured crenarchaeote amoA gene for ammonia monooxygenase subunit $A$ " accession number AB545944.1.

\section{Statistical Analyses}

We analyzed changes in nitrification potentials, cumulative inorganic $\mathrm{N}$, ammonia volatilization, and $\mathrm{AOB}, \mathrm{AOA}$ copy number per gram of soil as a function of manure application and time across a range of soil series via a completely randomized three factor factorial analysis of variance using SAS PROC MIXED (SAS Institute, 1997). Means were considered significantly different at the Bonferroni adjusted $p$-value of 0.01 . Spearman's rank correlation was used to test for monotonic trends among edaphic factors and cumulative inorganic $\mathrm{N}$ mineralized, nitrification potentials and $\mathrm{AOB}$ copy number per gram of soil measured at Day 28 of the $\mathrm{N}$ incubation using SAS PROC CORR. A Spearman's rank correlation coefficient and $p$-value were generated for each pair of variables. Soil properties included $\mathrm{pH}, \mathrm{TSN}, \mathrm{SOC}, \mathrm{pH}, \mathrm{CEC}, \mathrm{BD}$, the quantity (g $\mathrm{g}^{-1}$ ) of sand, silt and clay, clay mineralogy, and $\mathrm{AOB}, \mathrm{AOA}$ gene copy number per gram of soil. Minerals used in the Spearman's correlation were present in three or more soils and included kaolinite, illite, smectite, and vermiculite.

\section{Results}

\section{Nitrogen Mineralization and Nitrification}

The amount of $\mathrm{N}$ mineralized $\left(\mathrm{NH}_{4}, \mathrm{NO}_{2}\right.$, and $\left.\mathrm{NO}_{3}\right)-\mathrm{N}$ and net nitrification were dependent on specific soil properties. Inorganic $\mathrm{N}$ on Day 28 in soils without dairy slurry was positively correlated with SOC, TSN, CEC, and kaolinite. The manure-applied treatment revealed a positive correlation between cumulative inorganic $\mathrm{N}$ mineralized and CEC (Table 3). The S_VA soil had the lowest net nitrification values with or without dairy slurry application $\left(4.5\right.$ and $\left.9.4 \mathrm{~kg} \mathrm{ha}^{-1}\right)$ on Day 28 (Tables 4 and 5). Spearman's correlation coefficients for cumulative inorganic $\mathrm{N}$ mineralized were not positively correlated with illite and smectite, the dominant minerals in S_VA (Table 3). Soil series with the highest net nitrification, Sharpsburg silty clay (SIC_SH), Roshalt (SIL_RO), and Brooksville (SICL_BR), also contained vermiculite or smectite (Table 2) that can retain and release ammonium.

Nitrification rates varied between soils and increased significantly with manure application. Nitrification potentials taken a few minutes after application of dairy slurry (time zero) ranged from 2 to $10 \mathrm{mg} \mathrm{kg}^{-1} \mathrm{~d}^{-1}$ and were not significantly different in manured and unmanured treatments within a soil series (Table 6). Nitrification potentials did not differ among time intervals in soil samples without dairy slurry application but varied significantly between soil series ranging from 2 to $11 \mathrm{mg} \mathrm{kg}^{-1} \mathrm{~d}^{-1}$. Nitrification potentials increased between time of initial manure application and Day 7 ( 6 to $20 \mathrm{mg} \mathrm{kg}^{-1} \mathrm{~d}^{-1}$ ) and remained constant in the majority of the amended treatments throughout the remainder of the 28-d incubation (Table 6). Spearman's correlation coefficients in soils with and without dairy slurry applications revealed 
Table 3. Spearman correlations between edaphic properties and ammonia-oxidizing bacteria (AOB) copy number per gram of soil taken from Day 28 of a $\mathrm{N}$ incubation. $\dagger$

\begin{tabular}{|c|c|c|c|c|c|c|c|c|c|c|c|c|c|c|c|c|}
\hline & AOB_C & NP_D & NP_C & InOrgND & InOrgNC & SOC & TSN & $\mathrm{pH}$ & CEC & Sand & Silt & Clay & KK & IL & $S$ & VR \\
\hline AOB_D & $0.71^{* *}$ & 0.39 & $0.69 * *$ & -0.53 & $0.71 * *$ & $0.69^{* *}$ & $0.60^{*}$ & -0.06 & -0.06 & -0.07 & 0.41 & 0.17 & $0.67^{*}$ & $-0.76^{* *}$ & 0.48 & 0.39 \\
\hline AOB_C & & 0.41 & $0.86^{* *}$ & $-0.73^{* *}$ & 0.55 & $0.85^{* *}$ & $0.78^{* * *}$ & 0.08 & 0.31 & -0.23 & 0.07 & $0.58^{*}$ & 0.24 & -0.35 & 0.60 & -0.39 \\
\hline NP_D & & & $0.66^{*}$ & $-0.64^{*}$ & -0.26 & $0.66^{*}$ & $0.64^{*}$ & $0.88^{* *}$ & $0.66^{*}$ & -0.03 & -0.31 & 0.31 & -0.11 & 0.03 & $0.82^{* *}$ & -0.40 \\
\hline NP_C & & & & -0.55 & 0.31 & $0.99 * *$ & $0.98^{* *}$ & 0.37 & $0.60^{*}$ & -0.49 & 0.20 & $0.75^{* *}$ & 0.26 & -0.42 & $0.86^{*}$ & -0.40 \\
\hline InOrgND & & & & & -0.23 & -0.55 & -0.44 & -0.40 & $0.15^{*}$ & -0.32 & 0.45 & -0.15 & 0.20 & -0.06 & -0.50 & 0.40 \\
\hline InOrgNC & & & & & & $0.31^{* *}$ & $0.20^{* *}$ & $-0.66^{*}$ & $0.21^{* *}$ & 0.08 & 0.49 & -0.06 & $0.83^{* *}$ & $-0.77^{* *}$ & -0.50 & 0.60 \\
\hline SOC & & & & & & & $0.98^{* *}$ & 0.37 & $0.60^{*}$ & -0.48 & 0.20 & $0.75^{* *}$ & 0.25 & -0.43 & $1.00^{* *}$ & -0.40 \\
\hline TSN & & & & & & & & 0.40 & $0.70^{* *}$ & $-0.61^{*}$ & 0.23 & $0.84^{* *}$ & 0.20 & -0.40 & $1.00 * *$ & -0.40 \\
\hline $\mathrm{pH}$ & & & & & & & & & $0.77^{* *}$ & -0.03 & $-0.54^{*}$ & 0.28 & $-0.60^{*}$ & 0.43 & 0.50 & -0.40 \\
\hline CEC & & & & & & & & & & $-0.60^{*}$ & -0.20 & $0.81^{* *}$ & -0.48 & 0.31 & 0.50 & $-0.80^{*}$ \\
\hline
\end{tabular}

* Significant at $P<0.05$.

**Significant at $P<0.01$

† AOB_D, $A O B$ copy number per gram soil manured treatment; $A O B \_C, A O B$ copy number per gram soil unmanured treatment; $N P \_D$, nitrification

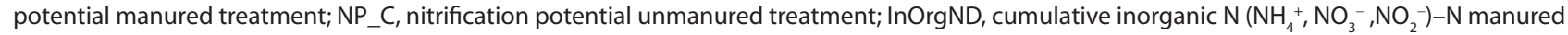

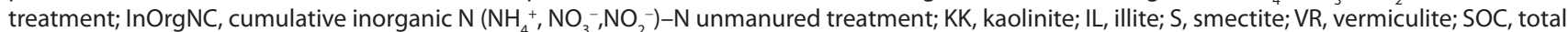
soil organic carbon; TSN, total soil nitrogen; CEC, cation exchange capacity.

Table 4. The effect of incubation time, soil series, and no dairy slurry on cumulative inorganic $\mathrm{N}_{\left(\mathrm{NH}_{4^{\prime}}\right.} \mathrm{NO}_{2^{\prime}}$, and $\left.\mathrm{NO}_{3}\right)-\mathrm{N} \mathrm{kg}$ ha-1 during a $28-\mathrm{d}$ incubation.

\begin{tabular}{|c|c|c|c|c|c|c|c|c|c|c|c|}
\hline \multirow{3}{*}{$\begin{array}{l}\text { Sample } \\
\text { code }\end{array}$} & \multirow{3}{*}{$\begin{array}{l}\text { Soil } \\
\text { series }\end{array}$} & \multirow{2}{*}{\multicolumn{5}{|c|}{$\frac{\text { Nitrate and nitrite }\left(\mathrm{NO}_{3}^{-}+\mathrm{NO}_{2}\right)-\mathrm{N}}{\text { Time interval } \dagger}$}} & \multicolumn{5}{|c|}{ Ammonium $\left(\mathrm{NH}_{4}^{+}\right)-\mathrm{N}$} \\
\hline & & & & & & & & & me inter & & \\
\hline & & $0 \mathrm{~d}$ & $7 \mathrm{~d}$ & $14 d$ & $21 d$ & $28 \mathrm{~d}$ & $0 \mathrm{~d}$ & $7 d$ & $14 \mathrm{~d}$ & $21 \mathrm{~d}$ & $28 \mathrm{~d}$ \\
\hline SIL_CA & Caribou & 21 eł & $40 \mathrm{j}$ & $52 \mathrm{~m}$ & $65 n$ & 820 & $2.6 \mathrm{bc}$ & $2.2 \mathrm{~b}$ & $6.6 \mathrm{~d}$ & $2.8 \mathrm{bc}$ & $2.6 \mathrm{bc}$ \\
\hline L_NE & Newport & $8.6 \mathrm{~b}$ & 19 de & $29 \mathrm{gh}$ & $41 \mathrm{jk}$ & $52 \mathrm{~m}$ & $2.9 \mathrm{bc}$ & $2.2 \mathrm{~b}$ & $4.3 c$ & $2.3 \mathrm{~b}$ & $2.9 \mathrm{bc}$ \\
\hline SIC_SH & Sharpsburg & 19 de & $24 \mathrm{f}$ & $28 \mathrm{~g}$ & $28 \mathrm{~g}$ & $32 \mathrm{hi}$ & $5.9 \mathrm{~d}$ & $1.4 \mathrm{a}$ & $1.8 \mathrm{ab}$ & $1.5 \mathrm{ab}$ & $1.4 \mathrm{ab}$ \\
\hline$S L \_A D$ & Adkins & $9.8 \mathrm{~b}$ & $13 c$ & $18 \mathrm{de}$ & $24 \mathrm{f}$ & $29 \mathrm{gh}$ & $2.2 \mathrm{~b}$ & $1.5 \mathrm{ab}$ & $1.1 \mathrm{ab}$ & $1.4 \mathrm{ab}$ & $0.99 a$ \\
\hline SIL_LO & Loyal & $18 d$ & $27 \mathrm{~g}$ & $34 \mathrm{i}$ & $42 \mathrm{jk}$ & $49 \mathrm{i}$ & $1.8 \mathrm{ab}$ & $2.0 \mathrm{ab}$ & $1.9 \mathrm{ab}$ & $1.4 \mathrm{a}$ & $1.6 \mathrm{ab}$ \\
\hline SIL_RO & Roshalt & $9.6 \mathrm{~b}$ & 22 ef & $32 \mathrm{hi}$ & $43 k$ & $47 i$ & $1.9 a b$ & $1.6 \mathrm{ab}$ & $1.8 \mathrm{ab}$ & $1.3 \mathrm{ab}$ & $2.8 \mathrm{bc}$ \\
\hline SICL_BR & Brooksville & $23 f$ & $31 \mathrm{~h}$ & $35 \mathrm{i}$ & $40 \mathrm{j}$ & $41 \mathrm{jk}$ & $5.4 \mathrm{~cd}$ & $1.6 \mathrm{ab}$ & $1.5 \mathrm{~b}$ & $3.4 c$ & $1.6 \mathrm{ab}$ \\
\hline SIC_CA & Catlin & $16 \mathrm{~cd}$ & $21 \mathrm{ef}$ & $29 \mathrm{gh}$ & $31 \mathrm{~h}$ & $35 \mathrm{i}$ & $4.0 \mathrm{c}$ & $1.8 \mathrm{ab}$ & $1.5 \mathrm{a}$ & $1.3 \mathrm{a}$ & $1.2 \mathrm{a}$ \\
\hline S_VA & Valentine & $4.0 \mathrm{a}$ & $2.6 a$ & $4.1 \mathrm{a}$ & $4.4 \mathrm{a}$ & $4.5 \mathrm{a}$ & $6.5 \mathrm{~d}$ & $14 \mathrm{e}$ & $22 \mathrm{f}$ & $24 \mathrm{f}$ & $24 \mathrm{f}$ \\
\hline
\end{tabular}

† Time interval of the incubation in days.

₹ Values followed by a different letter designated nitrate and nitrite or ammonium are significantly different at $p=0.01$. Calculated via a completely randomized three factor factorial analysis of variance in SAS Proc Mixed to determine the effect of dairy slurry management $\times$ soil series $\times$ time of incubation during a 28-d incubation.

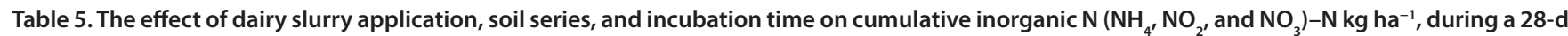
incubation.

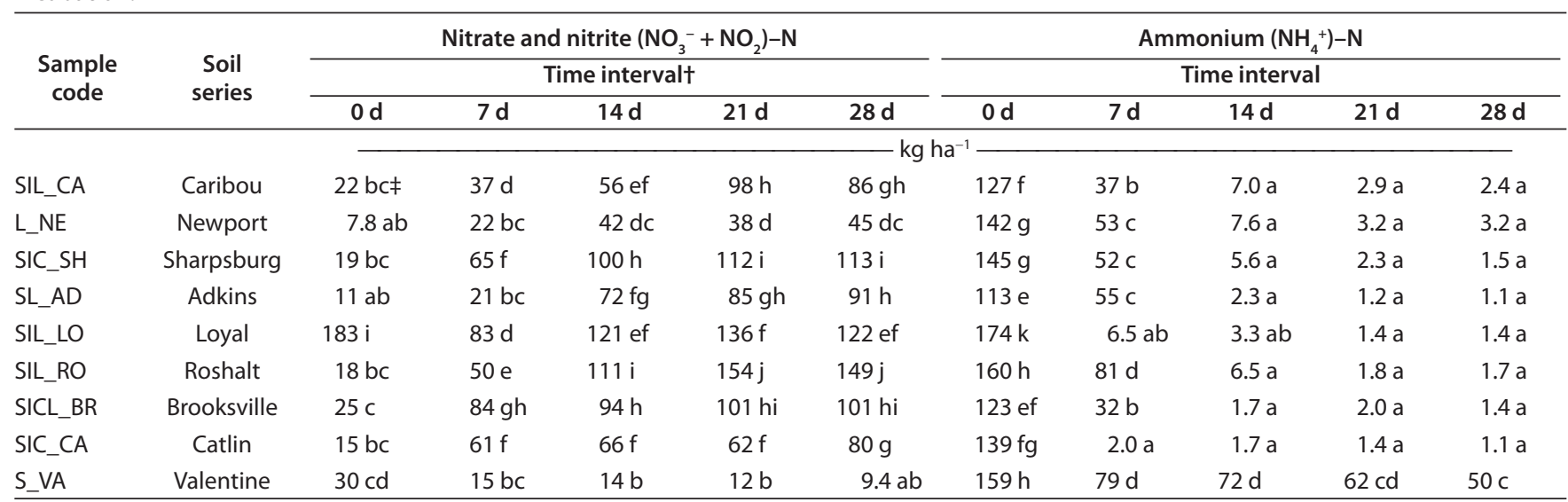

†Time interval of the incubation in days.

₹ Values followed by a different letter designated nitrate and nitrite or ammonium are significantly different at $p=0.01$. Calculated via a completely randomized three factor factorial analysis of variance in SAS Proc Mixed to determine the effect of dairy slurry management $\times$ soil series $\times$ time of incubation during a 28-d incubation. 
that nitrification potentials were positively correlated with SOC, TSN, CEC, and smectite (Table 3).

The presence or absence of specific clay minerals as well as texture influenced nitrification rates among soil series. The SL_AD soil, which had the lowest nitrification potentials in the control treatments (Table 6), contained the greatest quantity of sand $\left(730 \mathrm{~g} \mathrm{~kg}^{-1}\right)$ and lowest clay content $\left(60 \mathrm{~g} \mathrm{~kg}^{-1}\right)$ (Table 2). Rates of nitrification were lower in soils high in sand and silt (Table 6). Nitrification potentials in the manured SL_AD significantly increased from time 0 to $21 \mathrm{~d}$ (Table 6). Between Day 21 and 28, nitrification rates dropped significantly in the manured SL_AD treatment. This was the only soil on which nitrification potentials decreased during the $28 \mathrm{~d}$ after manure was applied.

Soil series high in clay that contained smectite (SICL_BR and SIC_CA) had elevated nitrification potentials. The nitrification rates taken from the SICL_BR and SIC_CA soils without manure had significantly higher nitrification potentials and high total clay content (320 and $400 \mathrm{~g} \mathrm{~kg}^{-1}$ ) (Tables 2 and 6). Smectite, a mineral that can retain and rerelease ammonium due to basal surface exchange, was the dominant or one of the dominant minerals in the SICL_BR and SIC_CA soils (Table 2). Smectite was significantly positively correlated $(p=0.01)$ with nitrification potential in both the dairy slurry and control treatments (Table 3).

The SIC_SH soil contained a similar quantity of total clay to SICL_BR and SIC_CA, but vermiculite (VR) was the dominant mineral and the $\mathrm{pH}$ was lower (Table 2). There was no significant correlation between VR and nitrification potentials (Table 3). The SIC_CA soil contained a mixture of clays (illite, smectite, and vermiculite) with high CEC and the potential to retain $\mathrm{NH}_{4}^{+}$. This soil had the highest nitrification rates in manured treatments and lowest $\mathrm{pH}$ (Tables 2 and 6). Higher $\mathrm{pH}$ across soil series was positively correlated with nitrification potentials (Table 3). Nitrification potentials in the SIC_CA and SICL_BR soil series were not significantly different in the absence of manuring (Table 6). The addition of manure to SIC_CA significantly increased nitrification potentials for Days 7 through 28 relative to the SICL_BR soil.

\section{Ammonia Volatilization}

As expected for soils with neutral to acidic $\mathrm{pH}$ values, ammonia volatilization was minimal in all soil series, ranging from 2.5 to $18 \mathrm{~kg} \mathrm{NH}_{4}^{+}-\mathrm{N} \mathrm{ha}^{-1}$. The highest losses occurred in soils containing high sand concentrations; i.e., the SL_AD treatment lost $17 \mathrm{NH}_{4}^{+}-\mathrm{N} \mathrm{kg} \mathrm{ha}{ }^{-1}$, and the S_VA treatment lost $18 \mathrm{NH}_{4}^{+}-\mathrm{N} \mathrm{kg} \mathrm{ha}{ }^{-1}$, equivalent to approximately $10 \%$ of the $\mathrm{NH}_{4}^{+}$applied in dairy slurry. Dairy slurry additions $(\mathrm{pH}$ 7.2) raised the $\mathrm{pH}$ of all soils by $0.1 \mathrm{pH}$ unit or less.

\section{Quantification of Ammonia-0xidizing Archaea and Ammonia-0xidizing Bacteria}

The use of a standard curve based on known concentrations of Nitrosomonas europaea ATCC 19718 provided $R^{2}$ values of 0.99 to 0.98 for all curves. Quantitative PCR assays for AOB contained a significant three-way interaction among soil series $x$ dairy slurry management $x$ time of incubation that resulted in different $\mathrm{AOB}$ gene copy numbers per gram of soil $(p=$ 0.01 ) (Table 7). Average AOB copy numbers in soils incubated for $28 \mathrm{~d}$ with and without dairy slurry tended to increase with incubation time and slurry applications. The trend of increasing $\mathrm{AOB}$ copy numbers was statistically significant in the no-slurry control treatments only in the SIL_CA soils ( $0 \mathrm{~d}$, $4.73 \times 10^{6}$ vs. $28 \mathrm{~d}, 1.69 \times 10^{7}$ ) and was a result of time of incubation. The copy numbers of AOB decreased after $28 \mathrm{~d}$ of incubation in only one no-slurry treatment the SIL_RO soil $\left(0 \mathrm{~d}, 8.30 \times 10^{6}\right.$ vs. $\left.28 \mathrm{~d}, 6.31 \times 10^{5}\right)$. Copy numbers of $\mathrm{AOB}$ were significantly higher on Day 28 relative to time zero in the unamended SIL_CA soil (Table 7).

Ammonia-oxidizing bacteria copy numbers were highly correlated with several nitrogen parameters and negatively correlated in manured treatments with illite, a mineral with edge and interlayer sites that sorb and potentially fix $\mathrm{NH}_{4}^{+}$. Spearman's correlation coefficients indicated that AOB gene copy numbers per gram of soil were positively correlated with nitrification potential and clay content in control treatments and SOC and TSN in manured and unmanured soils (Table $3)$. The AOB gene copy numbers per gram of soil in manured plots were positively correlated with cumulative inorganic $\mathrm{N}$ and kaolinite and negatively correlated with illite (Table 3).

Table 6. Nitrification potentials for a given time interval and soil series with and without dairy slurry applications.

\begin{tabular}{|c|c|c|c|c|c|c|c|c|c|c|c|}
\hline \multirow{3}{*}{$\begin{array}{l}\text { Sample } \\
\text { code }\end{array}$} & \multirow{3}{*}{$\begin{array}{l}\text { Soil } \\
\text { series }\end{array}$} & \multicolumn{5}{|c|}{ Control nitrification potentials } & \multicolumn{5}{|c|}{ Dairy slurry applied nitrification potentials } \\
\hline & & \multicolumn{5}{|c|}{ Time interval† } & \multicolumn{5}{|c|}{ Time interval } \\
\hline & & $\mathbf{0 d}$ & $7 \mathrm{~d}$ & $14 \mathrm{~d}$ & $21 \mathrm{~d}$ & $28 \mathrm{~d}$ & $\mathbf{0 d}$ & $7 \mathrm{~d}$ & $14 \mathrm{~d}$ & $21 \mathrm{~d}$ & $28 \mathrm{~d}$ \\
\hline & & & & & & $-\mathrm{mg}$ & $d^{-1}-$ & & & & - \\
\hline SIL_CA & Caribou & $5 \mathrm{bc} \neq$ & $5 \mathrm{bc}$ & $4 b$ & $5 \mathrm{bc}$ & $5 \mathrm{bc}$ & $3 a b$ & 11 ef & 11 ef & 11 ef & 11 ef \\
\hline L_NE & Newport & $4 \mathrm{~b}$ & $4 \mathrm{~b}$ & $4 \mathrm{~b}$ & $4 b$ & $4 \mathrm{~b}$ & $3 a b$ & 9 de & 11 ef & 11 ef & 11 ef \\
\hline SIC_SH & Sharpsburg & $4 b$ & $4 b$ & $4 b$ & $4 b$ & $4 \mathrm{~b}$ & $3 a b$ & $6 c$ & $9 \mathrm{de}$ & $8 \mathrm{de}$ & $8 \mathrm{de}$ \\
\hline SL_AD & Adkins & $2 a b$ & $2 a b$ & $3 a b$ & $2 a b$ & $2 a b$ & $2 a b$ & $8 d$ & $13 \mathrm{~g}$ & $17 \mathrm{~h}$ & $12 \mathrm{f}$ \\
\hline SIL_LO & Loyal & $6 c$ & $6 c$ & $6 c$ & $6 c$ & $7 \mathrm{~cd}$ & $5 \mathrm{bc}$ & $15 \mathrm{gh}$ & $15 \mathrm{gh}$ & $15 \mathrm{gh}$ & $15 \mathrm{gh}$ \\
\hline SIL_RO & Roshalt & $3 a b$ & $4 b$ & $4 b$ & $4 b$ & $4 \mathrm{~b}$ & $1 \mathrm{a}$ & $6 c$ & $6 c$ & $7 \mathrm{~cd}$ & $7 \mathrm{cb}$ \\
\hline SICL_BR & Brooksville & 10 ef & 11 ef & 10 ef & 11 ef & 11 ef & 10 ef & 11 ef & $12 \mathrm{f}$ & $13 \mathrm{~g}$ & $14 \mathrm{~g}$ \\
\hline SIC_CA & Catlin & 10 ef & 10 ef & 10 ef & 9 de & 10 ef & 10 ef & $20 i$ & $19 \mathrm{i}$ & $17 \mathrm{~h}$ & $19 \mathrm{i}$ \\
\hline
\end{tabular}

†Time interval of the incubation in days.

₹ Values followed by a different letter are significantly different at $p=0.01$. Calculated via a completely randomized three factor factorial analysis of variance in SAS Proc Mixed to determine the effect of dairy slurry management $\times$ soil series $\times$ time of incubation during a $28-d$ incubation. 
Table 7. The effect of dairy slurry management and time since slurry application on ammonia oxidizing bacteria (AOB) gene copy number per gram soil across a range of soil series.

\begin{tabular}{|c|c|c|c|c|c|}
\hline \multirow{2}{*}{$\begin{array}{l}\text { Sample } \\
\text { code }\end{array}$} & \multirow{2}{*}{$\begin{array}{l}\text { Soil } \\
\text { series }\end{array}$} & \multicolumn{2}{|c|}{ Control } & \multicolumn{2}{|c|}{ Dairy slurry } \\
\hline & & $0 \mathrm{dt}$ & $28 \mathrm{~d}$ & $0 \mathrm{~d}$ & $28 \mathrm{~d}$ \\
\hline SIL_CA & Caribou & $4.73 \times 10^{6} \mathrm{bc} \neq$ & $1.69 \times 10^{7} \mathrm{a}$ & $1.82 \times 10^{7} \mathrm{a}$ & $2.40 \times 10^{7} \mathrm{a}$ \\
\hline SIC_SH & Sharpsburg & $2.95 \times 10^{6} \mathrm{bc}$ & $4.76 \times 10^{6} \mathrm{bc}$ & $3.55 \times 10^{6} \mathrm{bc}$ & $3.60 \times 10^{6} \mathrm{bc}$ \\
\hline SL_AD & Adkins & $3.83 \times 10^{6} \mathrm{bc}$ & $2.85 \times 10^{6} \mathrm{c}$ & $8.23 \times 10^{6} \mathrm{ab}$ & $6.17 \times 10^{6} \mathrm{~b}$ \\
\hline SIL_LO & Loyal & $5.37 \times 10^{6} \mathrm{bc}$ & $3.48 \times 10^{6} \mathrm{bc}$ & $7.54 \times 10^{6} \mathrm{ab}$ & $5.47 \times 10^{6} \mathrm{bc}$ \\
\hline SIL_RO & Roshalt & $8.30 \times 10^{6} \mathrm{ab}$ & $6.31 \times 10^{5} \mathrm{~d}$ & $3.24 \times 10^{6} \mathrm{bc}$ & $9.50 \times 10^{6} \mathrm{ab}$ \\
\hline SIC_CA & Catlin & $7.47 \times 10^{6} \mathrm{ab}$ & $1.62 \times 10^{7} \mathrm{a}$ & $2.59 \times 10^{7} \mathrm{a}$ & $1.85 \times 10^{7} \mathrm{a}$ \\
\hline
\end{tabular}

†Time interval of the incubation in days.

¥ Values followed by a different letter are significantly different at $p=0.01$. Calculated via a completely randomized three factor factorial analysis of variance in SAS Proc Mixed to determine the effect of dairy slurry management $\times$ soil series $\times$ time of incubation during a 28 -d incubation.

Application of dairy slurry did not affect AOA gene copy numbers per gram of soil (Table 8). The use of a standard curve based on known concentrations of a TOPO vector containing the Nitrosopumilus maritimus SCM1 amoBAC gene insert provided $R^{2}$ values of 0.98 to 0.99 for all curves. Ammoniaoxidizing archaea gene copies ranged from $8.12 \times 10^{4}$ to $2.59 \times 10^{7} \mathrm{~g}^{-1}$ soil (Table 8). The length of incubation $\times$ soil series had a significant effect on AOA gene copy numbers in two soils. Incubating soil for $28 \mathrm{~d}$ significantly increased AOA copy numbers in the SIL_CA soil $\left(0 \mathrm{~d}, 1.01 \times 10^{5}\right.$ e vs. $\left.28 \mathrm{~d}, 1.56 \times 10^{6} \mathrm{c}\right)$ and decreased AOA copy numbers $(0 \mathrm{~d}$, $3.77 \times 10^{5} \mathrm{~d}$ vs. $28 \mathrm{~d}, 8.12 \times 10^{4}$ e) in the SL_AD soil. All other soils were unaffected by the incubation. On average, $\mathrm{AOB}$ gene copies were an order of magnitude greater than those of AOA (Table 7 and 8). Ammonia-oxidizing archaea copy numbers did not correlate with dairy slurry application and most edaphic properties. Therefore, correlations of AOA copy numbers are not presented.

\section{Discussion}

\section{Fate of Manure-Applied $\mathrm{NH}_{4}^{+}$}

Mineralization of organic $\mathrm{N}$ and the concentration of ammonium in soil have a direct effect on plant-available $\mathrm{N}$ and the process of nitrification. Mineralized $\mathrm{N}$ in the form of ammonium derived from soil and dairy slurry can be nitrified, immobilized by microbial biomass, incorporated into organic $\mathrm{N}$, fixed by clay minerals, held on exchange sites, or lost as

Table 8. The effect of soil and time of incubation on ammonia oxidizing archaea $(A O A)$ gene copy number per gram of soil across a range of soil series.

\begin{tabular}{lccc}
\hline \multirow{2}{*}{$\begin{array}{c}\text { Sample } \\
\text { code }\end{array}$} & Soil & \multicolumn{2}{c}{ Time intervalt } \\
\cline { 3 - 4 } series & Caribou & $1.01 \times 10^{5} \mathrm{e} \neq$ & $1.56 \times 10^{6} \mathrm{C}$ \\
\hline SIL_CA & Carpsburg & $3.26 \times 10^{6} \mathrm{bc}$ & $3.06 \times 10^{6} \mathrm{C}$ \\
SIC_SH & Sharpsburg & $3.77 \times 10^{5} \mathrm{~d}$ & $8.12 \times 10^{4} \mathrm{e}$ \\
SL_AD & Adkins & $1.90 \times 10^{7} \mathrm{a}$ & $2.59 \times 10^{7} \mathrm{a}$ \\
SIL_LO & Loyal & $1.43 \times 10^{5} \mathrm{de}$ & $1.42 \times 10^{5} \mathrm{de}$ \\
SIL_RO & Roshalt & $9.42 \times 10^{6} \mathrm{~b}$ & $1.24 \times 10^{7} \mathrm{~b}$ \\
SIC_CA & Catlin &
\end{tabular}

†Time interval of the incubation in days.

$\neq$ Values followed by a different letter are significantly different at $p=$ 0.01 . Calculated via a completely randomized three factor factorial analysis of variance in SAS Proc Mixed to determine the effect of dairy slurry $\times$ soil series $\times$ time of incubation during a $28-d$ incubation.

There was a significant two-way interaction between soil series $\times$ time of incubation.
$\mathrm{NH}_{3}$ and $\mathrm{N}_{2} \mathrm{O}$ (derived from nitrification and denitrification). Previous research showed that the majority of changes in net $\mathrm{N}$ transformations occur during the first $28 \mathrm{~d}$ following manure application (Griffin et al., 2005; Honeycutt et al., 2005; Sistani et al., 2008). Ammonium concentrations in our study were negligible after $7 \mathrm{~d}$ in all soils except the sand (S_VA). Increases in nitrification rates and their subsequent stabilization after $7 \mathrm{~d}$ coincided with the disappearance of $\mathrm{NH}_{4}^{+}$.

Incubation conditions during this study favored immobilization of inorganic $\mathrm{N}$ in microbial biomass or retention of inorganic $\mathrm{N}$ by mineral components. We chose conditions that minimized gaseous losses of $\mathrm{NH}_{3}$ and denitrification by control of soil water content and aeration. Ammonia volatilization in our study was equivalent to $10 \%$ or less of the amount of ammonium applied in the dairy slurry. Loss of ammonia from surface-applied animal slurries can be 40 to $60 \%$ of the $\mathrm{NH}_{4}^{+}$ content of slurries (Thompson et al., 1990).

Upon termination of our 28-d incubation, $\mathrm{KCl}$-extractable inorganic $\mathrm{N}$ ranged from 42 to $131 \mathrm{~kg} \mathrm{ha}^{-1}$ in treatments amended with dairy slurry. Our data suggest the potential for fixation of $\mathrm{NH}_{4}^{+}$on mineral exchange sites. Differences in the amount of ammonium that can interact with exchange sites and be rereleased or fixed by a clay is dependent on the amount and types of exchange sites present in a particular mineral (Sawhney, 1972). Illite is a more effective fixer of $\mathrm{NH}_{4}^{+}$ than smectite or vermiculite and may reduce the availability of $\mathrm{NH}_{4}^{+}$. Therefore, we estimated the amount of $\mathrm{NH}_{4}^{+}$that could be adsorbed to selective sites on illite. Although only an approximation, it gives an idea of the potential "fixed" $\mathrm{NH}_{4}$ that would not be extractable by $\mathrm{KCl}$ and only slowly available to microorganisms. Because most fixation by clays occurs in the first days of incubation (Drury and Beauchamp, 1991), we estimated the fraction of nonextractable $\mathrm{NH}_{4}^{+}$fixed by illite at Day 7. The fractions ranged from $0 \%$ for SICL_BR, which had $320 \mathrm{~g}$ clay $\mathrm{kg}^{-1}$ but no illite or vermiculite, to $44 \%$ for SIC_CA with $400 \mathrm{~g}$ clay $\mathrm{kg}^{-1}$ containing both illite and vermiculite. The potential for vermiculite fixation of $\mathrm{NH}_{4}$ could not be determined because no average data are available for the quantity of selective sites in vermiculite.

Clay minerals with high CEC and frayed edges and/or basal sites, such as smectite, can provide a consistent source of exchangeable $\mathrm{NH}_{4}^{+}$ions (Sawhney, 1972) that will support populations of nitrifiers found in biofilms on clay surfaces (Powell and Prosser, 1991). Fluctuations in nitrification potential among time intervals and soil series may be due to 
the fixation by illite or retention of $\mathrm{NH}_{4}^{+}$by smectite and vermiculite and rerelease of $\mathrm{NH}_{4}^{+}$from smectite. Other researchers have shown fixation and retention of $\mathrm{NH}_{4}^{+}$by clay minerals to be an important source of crop N (Mamo et al., 1993). The lower $\mathrm{pH}$ on the SIC_SH, and the dominance of illite and vermiculite, likely contributed to lowered nitrification potentials in this particular soil. Nitrifiers have been shown to inhabit surfaces of clays to protect themselves from, and minimize the effects of, hydrogen ions, allowing for nitrification to occur for longer periods of time under suboptimal conditions (Powell and Prosser, 1991).

\section{Can Process Level Functions such as Nitrification Be Linked to Ammonia-0xidizing Archaea and Ammonia- Oxidizing Bacteria Gene Copy Numbers?}

Ammonia-oxidizing bacteria gene copy numbers and nitrification rates were influenced by manuring, management history and edaphic properties such as soil texture, mineralogy, TSN, and SOC. The current study revealed correlations among $\mathrm{AOB}$ copy number, nitrification potentials, SOC, TSN, smectite, kaolinite, and illite. Smectite that potentially releases exchangeable $\mathrm{N}$ was positively correlated with increased nitrification potential, and illite that fixes $\mathrm{NH}_{4}^{+}$was negatively correlated with AOB copy number. Positive correlations between TSN, SOC, and CEC are likely associated with increases in $\mathrm{NH}_{4}^{+}$ ions, the substrate for nitrifiers and the nitrification process. Increases in each of these edaphic properties will often increase $\mathrm{NH}_{4}^{+}$. Previous measurements of microbial community characteristics such as substrate utilization and fatty acid methyl ester profiles taken during a separate study of the SIL_CA, SIC_CA, and L_NE soils with and without manure were also highly correlated with soil properties (Larkin et al., 2006).

Ammonia-oxidizing archaea copy numbers were equal to or less than AOB copy numbers in all soils except the SIL_RO, the soil with the lowest nitrification potential. The AOB gene copies were highest in SIL_CA and SIC_CA soils. Dairy slurry applications had no effect on AOA copy numbers and did not always result in an increase in $\mathrm{AOB}$ gene copies despite increases in nitrification potential with dairy slurry application. These results indicated that increases in cell activity could explain a portion of the change in nitrification potential. Reported cell activities for $\mathrm{AOB}$ are higher than those of AOA (Herrmann et al., 2008), and AOA are reported to be more active when ammonium is limited (Taylor et al., 2010). Manure additions were shown to increase the activity per cell during a 29-d incubation at $28^{\circ} \mathrm{C}$ (Laanbroek and Gerards, 1991) and are known to reduce or have no effect on AOA populations (Nicol et al., 2004). Potential nitrification activity in the former study increased due to higher specific activities of nitrifying bacteria, but the quantity of nitrifiers was not significantly different in manured and unmanured treatments (Laanbroek and Gerards, 1991). An additional study determined that rapid changes in $\mathrm{NH}_{4}^{+}-\mathrm{N}$ concentrations had an effect on the rate of substrate oxidation and bicarbonate uptake in several species of AOB (Belser, 1984). Rates were independent of nitrifier growth rates. High concentrations of $\mathrm{NH}_{4}^{+}$and bicarbonate from liquid manure applied to a 20-d incubation increased the extent and duration of nitrification (Petersen et al., 1991).
Application of dairy slurry may have had a similar effect during our incubation.

Prior land-use management may have had an important effect on nitrification and AOB copy numbers. The SIC_CA soil had one of the highest initial numbers of $\mathrm{AOB}$ gene copies before application of slurry. This soil had been cropped, but not for the past 7 yr. Prior fertilizer applications may have caused a change in $\mathrm{AOB}$ community composition and/or biomass such that the AOB population could respond immediately to $\mathrm{NH}_{4}^{+}$inputs without an increase in gene copies. A study from Rothamsted revealed that despite low AOB activity before fertilization, application of ammonium nitrate caused an immediate response to $\mathrm{NH}_{4}^{+}$additions, resulting in increased nitrification in wheat plots (Mendum et al., 1999). In the Rothamsted study, nitrifier populations had maintained a high metabolic potential despite previous static conditions. Ammonia-oxidizing bacteria population growth rates were 0.5 to 1 cellular division per week (Mendum et al., 1999). Gene copy numbers of $A O B$ remained constant or increased slightly in all soils receiving manure with the exception of the SIL_RO soil. The SIL_RO soil had low nitrification potentials even in the presence of manure $\mathrm{NH}_{4}^{+}$, the least number of $\mathrm{AOB}$ and the highest number of AOA. These results suggest that $\mathrm{AOA}$ in this soil may inhabit niches unfavorable to AOB.

The current and continuing debate over the role of $A O A$ in terrestrial $\mathrm{N}$ cycling is important. Estimates of oxidation rates per cell in fertilized and no-input systems indicate the potential for an additional community of nitrifiers. Estimates of oxidation rates per $\mathrm{AOB}$ cell in microcosms amended with 1.5 and $7.5 \mathrm{mM} \mathrm{NH}_{4}^{+}$ranged from 0.5 to $25 \mathrm{fmol}$ of $\mathrm{NH}_{4}^{+} \mathrm{h}^{-1}$ cell $^{-1}$ (Okano et al., 2004). These rates and estimates used by BoyleYarwood et al. (2008) indicate that the majority of nitrification that occurs in soil can be attributed to $\mathrm{AOB}$ populations. Our research indicates that $A O A$ gene copy numbers tended to be lower than those of $\mathrm{AOB}$ and did not respond to manure $\mathrm{N}$ additions. Reported cell activities for $\mathrm{AOB}$ are higher than those of AOA (Herrmann et al., 2008). Therefore, equal numbers of $\mathrm{AOB}$ and $\mathrm{AOA}$ copies would not contribute equally to nitrification rates, which provides further evidence that $\mathrm{AOB}$ is likely to be the predominant nitrifier in our soils. Our data indicate that soil properties such as mineralogy, TSN, SOC, $\mathrm{CEC}$, and cumulative inorganic $\mathrm{N}$, as well as manure management, affect $\mathrm{AOB}$ copy numbers and nitrification rates due to their impact on environmental conditions and the quantity and duration of the ammonium supplied to nitrifiers.

Despite such findings, nitrification rates from our study and others would allow for a potential contribution of AOA. Recent work conducted across fallow, pasture, and forest systems suggests that in certain niche ecosystems, AOA may be the sole contributor or the dominant source of nitrification (Taylor et al., 2010). Nitrifying archaea are found in agronomic systems that receive higher $\mathrm{N}$ inputs than grassland and forest systems (Taylor et al., 2010). However, activity of AOA in agricultural soils has not been shown to respond to, or to remain constant, after ammonia addition (Di et al., 2010; Jia and Conrad, 2009). In contrast to AOB, which are obligate chemoautotrophs (Koops and Pommerening-Röser, 2001), research conducted by Zhang et al. (2010) indicates that AOA isolated and cultured from soil have the ability to grow on an 
organic source of $\mathrm{C}$, pyruvate, and grow more effectively in mixtures of other microorganisms. This research thus indicates that soil AOA may not be strict autotrophs that use $\mathrm{CO}_{2}$ only. For the soils described in this study, our data indicate that nitrification rates were controlled by AOB.

\section{Conclusions}

This study provides new information with respect to the microbial ecology of nitrifiers and their niche across a range of manure-amended soils of varying edaphic properties. Currently, authors can find no other studies that compare AOA and AOB communities across as wide a range of soils under laboratory or in situ conditions. Our data indicate that soil properties such as mineralogy, TSN, SOC, and CEC, as well as manure management, affect $\mathrm{AOB}$ copy numbers and nitrification rates due to their impact on environmental conditions and the quantity and duration of the ammonium supplied to nitrifiers. Smectite, which has the potential to release exchangeable $\mathrm{N}$, was positively correlated with increases in nitrification rates, and illite, with the potential to fix $\mathrm{NH}_{4}^{+}$, was negatively correlated with $\mathrm{AOB}$ copy number. Ammoniaoxidizing archaea gene copies were lower or equal to those of $\mathrm{AOB}$ and did not increase after dairy slurry additions. The one soil in which AOA copy numbers were higher than AOB had the lowest nitrification potential. Our research suggests that $\mathrm{AOB}$ are the dominant nitrifiers in these predominantly fallow agricultural soils. These two nitrifier communities inhabit the same environment but respond differently to soil properties and vary in their growth conditions and potential contribution to nitrification rates.

\section{Acknowledgments}

Funding for this project was provided by Hatch Project 0711 and Congressional appropriations to ARS.

\section{References}

Aakra, Å., M. Hesselsøe, and L.R. Bakken. 2000. Surface attachment of ammonia-oxidising bacteria in soil. Microb. Ecol. 39:222-235.

Accoe, F., P. Boeckx, J. Busschaert, G. Hofman, and O. Van Cleemput. 2004 Gross $\mathrm{N}$ transformation rates and the net $\mathrm{N}$ mineralization rates related to the $\mathrm{C}$ and $\mathrm{N}$ contents of soil organic matter fractions in grassland soils of different age. Soil Biol. Biochem. 36:2075-2087. doi:10.1016/j. soilbio.2004.06.006

Bajwa, M.I. 1982. Soil clay mineralogies in relation to fertility management: Effect of clay mineral types on ammonium fixation under conditions of wetland rice culture. Agron. J. 74:143-144. doi:10.2134/agronj1982.0 $0021962007400010037 \mathrm{x}$

Belser, L.W. 1984. Bicarbonate uptake by nitrifiers: Effects of growth rate, $\mathrm{pH}$, substrate concentration, and metabolic inhibitors. Appl. Environ. Microbiol. 48:1100-1104.

Blake, G.R., and K.H. Hartge. 1986. Bulk density. p. 363-375. In A. Klute (ed.) Methods of soil analysis. Part 1. 2nd ed. SSSA and ASA, Madison, WI.

Bosatta, E., and G.L. Agren. 1998. Theoretical analyses of soil texture effects on organic matter dynamics. Soil Biol. Biochem. 29:1633-1638. doi:10.1016/S0038-0717(97)00086-2

Boyle-Yarwood, S.A., P.J. Bottomley, and D.D. Myrold. 2008. Community composition of ammonia-oxidizing bacteria and archaea in soils under stands of red alder and Douglas fir in Oregon. Environ. Microbiol. 10:2956-2965. doi:10.1111/j.1462-2920.2008.01600.x

Burt, R. 2004. Soil Survey laboratory methods manual. Soil Survey Investigations Rep. 42. U.S. Gov. Print. Office, Washington, DC.

Curtin, D., and C.A. Campbell. 2008. Mineralizable nitrogen. p. 599-606. In M.R. Carter and E.G. Gregorich (ed.) Soil sampling and methods of analysis. 2nd ed. Canadian Society of Soil Science, Pinawa, Manitoba.
Di, H.J., K.C. Cameron, J.-P. Shen, C.S. Winefield, M. O'Callaghan, S. Bowatte, and J.-Z. He. 2010. Ammonia-oxidizing bacteria and archaea grown under contrasting soil nitrogen conditions. FEMS Microbiol. Ecol. 72:386-394. doi:10.1111/j.1574-6941.2010.00861.x

Di, H.J., K.C. Cameron, J.P. Shen, C.S. Winefield, M. O'Callaghan, S. Bowatte, and J.Z. He. 2009. Nitrification driven by bacteria and not archaea in nitrogen rich grassland soils. Nat. Geosci. 2:621-624. doi:10.1038/ngeo613

Drury, C.F., and E.G. Beauchamp. 1991. Ammonium fixation, release, nitrification, and immobilization in high- and low-fixing soils. Soil Sci. Soc. Am. J. 55:125-129. doi:10.2136/sssaj1991.03615995005500010022x

Gavlak, R.G., D.A. Horneck, and R.O. Miller. 1994. Plant, soil, and water reference methods for the western region. Western Regional Extension Publ. 125. Univ. of Alaska, Fairbanks.

Griffin, T.S., Z. He, and C.W. Honeycutt. 2005. Manure composition affects net transformation of nitrogen from dairy manures. Plant Soil 273:2938. doi:10.1007/s11104-004-6473-5

Hart, S.C., J.M. Stark, E.A. Davidson, and M.K. Firestone. 1994. Nitrogen mineralization, immobilization, and nitrification. p. 1011-1018. In R.W. Weaver, J.S. Angle, P.S. Bottomley, D. Bezdicek, S. Smith, M.A. Tabatabai, and A. Wollum (ed.) Methods of soil analysis. Part 2. Microbiological and biochemical properties. SSSA Book Ser. 5. SSSA and ASA, Madison, WI.

Herrmann, M., A.M. Saunders, and A. Schramm. 2008. Archaea dominate the ammonia-oxidizing community in the rhizosphere of the freshwater macrophyte Littorella uniflora. Appl. Environ. Microbiol. 74:32793283. doi:10.1128/AEM.02802-07

Hermansson, A., and P.-E. Lindgren. 2002. Quantification of ammonia-oxidizing bacteria in arable soil by real-time PCR. Appl. Environ. Microbiol. 67:972-976. doi:10.1128/AEM.67.2.972-976.2001

Honeycutt, C.W., T.S. Griffin, B.J. Wienhold, B. Eghball, S.L. Albrecht, J.M. Powell, B.L. Woodbury, K.R. Sistani, R.K. Hubbard, and H.A. Torbert. 2005. Protocols for nationally coordinated laboratory and field research on manure nitrogen mineralization. Commun. Soil Sci. Plant Anal. 36:2807-2822. doi:10.1080/00103620500304184

Jia, Z., and R. Conrad. 2009. Bacteria rather than Archaea dominate microbial ammonia oxidation in an agricultural soil. Environ. Microbiol. 11:1658-1671. doi:10.1111/j.1462-2920.2009.01891.x

Koops, H. P., and A. Pommerening-Röser. 2001. Distribution and ecophysiology of the nitrifying bacteria emphasizing cultured species. FEMS Microbiol. Ecol. 37:1-9.

Laanbroek, H.J., and S. Gerards. 1991. Effects of organic manure on nitrification in arable soils. Biol. Fertil. Soils 12:147-153. doi:10.1007/ BF00341492

Larkin, R.P., C.W. Honeycutt, and T.S. Griffin. 2006. Effect of swine and dairy manure amendments on microbial communities in three soils as influenced by environmental conditions. Biol. Fertil. Soils 43:51-61. doi: $10.1007 / s 00374-005-0060-7$

Lehtovirta, L.E., J.I. Prosser, and G.W. Nicol. 2009. Soil pH regulates the abundance and diversity of Group 1.1c Crenarchaeota. FEMS Microbiol. Ecol. 70:367-376. doi:10.1111/j.1574-6941.2009.00748.x

Leininger, S., T. Urich, M. Schloter, L. Schwark, J. Qi, G.W. Nicol, J.I. Prosser, S.C. Schuster, and C. Schleper. 2006. Archaea predominate among ammonia-oxidizing prokaryotes in soils. Nat. Lett. 442:806-809. doi: $10.1038 /$ nature 04983

Mamo, M., R.W. Taylor, and J.W. Shuford. 1993. Ammonia fixation by soil and pure minerals. Commun. Soil Sci. Plant Anal. 24:1115-1126. doi: $10.1080 / 00103629309368864$

Martens-Habbena, W., P.M. Berube, H. Urakawa, J.R. de la Torre, and D.A. Stahl. 2009. Ammonia oxidation kinetics determine niche separation of nitrifying archaea and bacteria. Nature 461:976-979. doi:10.1038/ nature 08465

McLean, E.O. 1982. Soil pH and lime requirement. p. 199-223. In A.L. Page, R.H. Miller, and D.R. Keeney (ed.) Methods of soil analysis. Part 2. Chemical and microbiological properties. 2nd ed. SSSA Book Ser. 5. SSSA and ASA, Madison, WI.

Mendum, T.A., R.E. Sockett, and P.R. Hirsch. 1999. Use of molecular and isotopic techniques to monitor the response of autotrophic ammonia-oxidizing populations of the $\beta$ subdivision of the class Proteobacteria in arable soils to nitrogen fertilizer. Appl. Environ. Microbiol. 65:4155-4162.

Meunier, A., and B. Velde. 2004. Illite: Origins, evolution and metamorphism. Springer, Berlin.

Moore, D.M., and R.C. Reynolds. 1997. Sample preparation techniques for clay minerals. p. 204-226. In D.M. Moore and R.C. Reynolds (ed.) Xray diffraction and the identification and analysis of clay minerals. 2nd ed. Oxford Univ. Press, New York. 
Mulvaney, R.L. 1996. Nitrogen: Inorganic forms. p. 1123-1184. In D.L. Sparks et al. (ed.) Methods of Soil Analysis. Part 3. SSSA Book Ser. 5. SSSA and ASA, Madison, WI.

Nicol, G.W., G. Webster, L.A. Glover, and J.I. Prosser. 2004. Differential response of archaeal and bacterial communities to nitrogen inputs and $\mathrm{pH}$ changes in upland pasture rhizosphere soil. Environ. Microbiol. 6:861867. doi:10.1111/j.1462-2920.2004.00627.x

Norton, J.M., J.J. Alzerreca, Y. Suwa and M.G. Klotz. 2002. Diversity of ammonia monooxygenase operon in autotrophic ammonia-oxidizing bacteria. Arch. Microbiol. 177:139-149. doi:10.1007/s00203-001-0369-z

Okano, Y., K.R. Hristova, C.M. Leutenegger, L.E. Jackson, R.F. Denison, B. Gebreyesus, D. Lebauer, and K.M. Scow. 2004. Application of real-time PCR to study effects of ammonium on population size of ammoniaoxidizing bacteria in soil. Appl. Environ. Microbiol. 70:1008-1016. doi:10.1128/AEM.70.2.1008-1016.2004

Petersen, S.O., K. Henriksen, and T.H. Blackburn. 1991. Coupled nitrification-denitrification associated with liquid manure in a gel-stabilized model system. Biol. Fertil. Soils 12:19-27. doi:10.1007/BF00369383

Powell, S.J., and J.I. Prosser. 1991. Protection of Nitrosomonas europaea colonizing clay minerals from inhibition by nitrapyrin. J. Gen. Microbiol. 137:1923-1929.

Ross, D.S. 1995. Recommended methods for determining soil cation exchange capacity. p. 62-64. In Recommended soil testing procedures for the northeastern United States. 2nd ed. Northeastern Regional Publ. 493. Agriculture Experiment Station, Univ. of Delaware, Newark.

Russell, C.A., G.P. Robertson, E.A. Paul, and K.R. Kosola. 2004. Nitrogen cycling in popular stands defoliated by insects. Biogeochemistry 68:365381. doi:10.1023/B:BIOG.0000031038.70805.28

SAS Institute. 1997. SAS/STAT software changes and enhancements through release 6.12. SAS Inst., Cary, NC.

Sawhney, B.L. 1972. Selective sorption and fixation of cations by clay minerals: A review. Clays Clay Miner. 20:93-100. doi:10.1346/ CCMN.1972.0200208

Schauss, K., A. Focks, S. Leininger, A. Kotzerke, H. Heuer, S. ThieleBruhn, S. Sharma, B.-M. Wilke, M. Matthies, K. Smalla, J.C. Munch, W. Amelung, M. Kaupenjohann, M. Schloter, and C. Schleper. 2009. Dynamics and functional relevance of ammonia-oxidizing archaea in two agricultural soils. Environ. Microbiol. 11:446-456. doi:10.1111/j.1462-2920.2008.01783.x

Sistani, K.R., A. Adeli, S.L. McGowen, H. Tewolde, and G.E. Brink. 2008. Laboratory and field evaluation of broiler litter nitrogen mineralization.
Bioresour. Technol. 99:2603-2611. doi:10.1016/j.biortech.2007.04.069

Smith, R.V., R.M. Doyle, L.C. Burns, and R.J. Stevens. 1997. A model for nitrite accumulation in soils. Soil Biol. Biochem. 29:1241-1247. doi:10.1016/S0038-0717(97)00028-X

Stanford, G., and S.J. Smith. 1972. Nitrogen mineralization potentials of soils. Soil Sci. Soc. Am. Proc. 36:465-472. doi:10.2136/ sssaj1972.03615995003600030029x

Taylor, A.E., L.H. Zeglin, S. Dooley, D.D. Myrold, and P.J. Bottomley. 2010. Evidence for different contributions of archaea and bacteria to the ammonia-oxidizing potential of diverse Oregon soils. Appl. Environ. Microbiol. 76:7691-7698. doi:10.1128/AEM.01324-10

Thompson, R.B., B.F. Pain, and Y.J. Rees. 1990. Ammonia volatilization from cattle slurry following surface application to grassland: II. Influence of application rate, wind speed and applying slurry in narrow bands. Plant Soil 125:119-128.

USDA-ERS. 2001. Confined animal and manure nutrient data system. Available at http://www.ers.usda.gov/data/MANURE (verified 27 Sept. 2011).

USDA-NASS. 2004. 2002 census of agriculture. Available at http://www.nass. usda.gov/Census_of_Agriculture/index.asp (verified 27 Sept. 2011).

Whittig, L.D., and W.R. Allardice. 1986. X-ray diffraction techniques. p. 331-362. In A. Klute (ed.) Methods of soil analysis. Part 1. 2nd ed. SSSA Book Ser. 5. SSSA and ASA, Madison, WI.

Webster, G., T.M. Embley, T.E. Frietag, Z. Smith, and J.I. Prosser. 2005. Links among ammonia oxidizer species composition, functional diversity and nitrification kinetics in grassland soils. Environ. Microbiol. 7:676-684. doi:10.1111/j.1462-2920.2005.00740.x

Wolf, N. 2003. Determination of manure pH. p. 48-49. In John Peters (ed.) Recommended methods of manure analysis. Univ. of Wisconsin System, Madison.

Wuchter, C., B. Abbas, M.J. Coolen, L. Herfort, J. van Bleijswijk, P. Timmers, M. Strous, E. Teira, G.J. Herndl, J.J. Middelburg, S. Schouten, and J.S. Sinninghe Damsté. 2006. Archaeal nitrification in the ocean. Proc. Natl. Acad. Sci. USA 103:12317-12322. doi:10.1073/pnas.0600756103

You, J., A. Das, E.M. Dolan, and Z. Hu. 2009. Ammonia-oxidizing archaea involved in nitrogen removal. Water Res. 43:1801-1809. doi:10.1016/j. watres.2009.01.016

Zhang L.M., P.R. Offre, J.Z. He, D.T. Verhamme, G.W. Nicol, and J.I. Prosser. 2010. Autotrophic ammonia oxidation by soil thaumarchaea. Proc. Natl. Acad. Sci. USA 107:17240-17245. 